\title{
REINHARD SCHULZE'S QUEST FOR AN ISLAMIC ENLIGHTENMENT
}

\author{
BY \\ RUDOLPH PETERS \\ Amsterdam
}

During the last two decades the 18th century has almost become a fashionable topic of research among historians of the Islamic world. Till then this era was regarded either as a decrepit extension to the flourishing of Islamic civilization, studied only to give the heyday of Islam more relief, or as the background to 'modernization', studied in order to provide a starting point to measure the effects of the impact of the West. The Islamic world in the 18th century was regarded as dead and lifeless, passive and incapable of producing change by itself. It had to be brought to life by Western penetration (Edward Said has already pointed at the sexual imagery in these conceptions). The 18th century was therefore not deemed worthy of being studied for its own sake.

Until recently this view prevailed both in the West and the Islamic World. That the interest in the 18th century has recently increased is due, I believe, to the growing insight, also among historians of Islam, that periods of so-called cultural decadence can be interesting topics of research, too, and to the increasing awareness of the continuity between the 18th and 19th centuries.

However, in spite of this new scholarly interest much of the 18th century is still terra incognita. This is especially true of social and cultural history. The intellectual production of the 18th century has hardly been studied and is, therefore, in Schulze's phrase "unreadable" ("nicht lesbar", cf. supra, p. 153), in the sense that we fail to understand the allusions and associations of these texts and cannot relate them to each other and to their social and political context. Now, if Schulze calls for a greater effort in "decoding" 18th Islamic century literature-of whatever type-, I heartily 
agree. Although I think that the "unreadability" of 18th century writings is not as comprehensive as Schulze suggests-I do not think that e.g. figh or kalâm texts will offer too many problems-, there is certainly much work to be done, especially in the fields of belles lettres and mystical writings. This is in itself a worthy enterprise aiming at removing the white spots on our map of Islamic history.

For Schulze, however, there is a further, more ambitious objective: studying the Islamic 18th century in order to discover the Islamic roots of renewal. He seems to assume that the 18th century Islamic world, like 18th century Western Europe, contained germs of innovation and wants to adjust the current view that renewal and modernization of the Islamic world were exclusively due to Western influence. He points out that the historiography of the 16th century has established that the creation of a world economy was the result of the interaction of previously separated regional systems, and not only caused by the rise of Western European commercial capitalism. This universalistic view, he tells us, has not been extended to the 18th century. After 1700, the West occupies an historiographical monopoly in the sense that the specific developments in Western Europe have become the yardstick for measuring and judging what happened in the rest of the world. Positing that the Islamic world has participated in the universality of the 18th century seems almost an insult, Schulze tells us, since that might imply the existence of an Islamic Enlightenment, and an Islamic secularisation of knowledge, power etc.

Schulze not only assumes that in the 18 th century Islamic world autonomous agents of innovation can be found, but also that this innovation deserves to be labeled as Islamic Enlightenment, because it is similar to Western Enlightenment, if the latter is stripped of its Western specificity. And tentatively he points out that we might find in 18th century Islamic mysticism and even in Islamic jurisprudence a tendency to replace the theocentric worldview with a more anthropocentric one, founded on the assumption of man's capability to create his own order.

Now here I cannot follow him anymore. I do agree that it is important for Islamic historiography to look for indigenous agents of innovative change in the 18th century and for the continuity of 
Islamic history from the 18 th to the 19 th and 20 th centuries. However, I think our knowledge of the 18th century has not advanced to the degree that we can positively state that these agents were there and identify them. Secondly, in our attempts to universalize historiography we should not forget that Western European Enlightenment is closely associated with a specific political, social and economic development, which did not occur in the Islamic world. This whole complex, including the intellectual and cultural factors, made the Western world what it is today. Now, if we should find in the Islamic world during the 18th century cultural and intellectual expressions that show some similarity with some basic concepts of the Enlightenment, I think it is not justified to label them as "Enlightenment". In the first place, it would be confusing and would strip the concept of Enlightenment of its precise meaning. And secondly, it would imply isolating the cultural and intellectual sphere from the other historical developments. This would only be justified if one adheres-which I am sure Schulze does not-to an extremely idealistic view of history that regards ideas as the primary motor of historical development.

I think that a compulsive search for, often flimsy, similarities between the Islamic and the Western European 18th century is not the right approach to universalizing historiography. We should not turn a blind eye to the existing differences. The greatest historiographical challenge, then, is to bring the 18th century to life again, to show through research that this era is not as sterile, dead and stagnating as it is often portrayed. Even if we have to admit that culturally it is perhaps not one of the flourishing periods of Islamic history, it is without doubt possible to show that it has its own dynamism and vitality and its own character by which it is distinguished from the previous and the following centuries. 